\title{
ANALISIS DESAIN WEBSITE BNI, BUKOPIN, J.CO DONUTS DAN MCDONALS MENURUT BUKU “THE PRINCIPLES OF BEAUTIFUL WEB DESIGN"
}

\author{
Fitria Ekarini \\ Prodi Teknik Elektronika dan Informatika, Pascasarjana UNY \\ Email: -
}

\begin{abstract}
ABSTRAK
Paper ini bertujuan untuk mengetahui hasil analisis desain beberapa tampilan website berdasarkan teori “The Principle Beautiful Web Design" menggunakan tujuh variabel antara lain Defining good Design, Web Page Anatomy, Grid Theory, Balance, Unity, Bread and Butter Layout dan Fresh Trends. Penelitian ini membandingkan empat website yang terdiri 2 jenis website perbankan dan 2 jenis food company. yaitu website BNI, website Bank BUKOPIN, website Jco Donuts, dan website McDonals. Hasilnya didapatkan bahwa website food company lebih baik dalam desain tampilan websitenya dibandingan dengan website perbankan. Dalam website food company hampir seluruh variabel digunakan dalam mendesain tampilan websitenya.
\end{abstract}

Kata kunci: The Priciples of Beautiful Web Design, website

\section{PENDAHULUAN}

Dalam mengembangkan suatu website, ada beberapa hal yang perlu diperhatikan agar situs tersebut dapat menarik perhatian pengunjung. Apalagi di zaman modern seperti sekarang ini, dimana internet sudah tidak asing lagi bagi masyarakat, semakin banyak pula situs-situs yang bermunculan dalam dunia internet. Untuk menarik perhatian pengunjung, desain website yang baik sangat diperlukan. Dengan desain website yang baik, tidak hanya dapat menarik pengunjung saja, tetapi pengunjung juga dapat merespon tujuan dari website tersebut dan mau mengunjunginya kembali.

Kriteria website yang baik dapat dilihat dari beberapa hal antara lain: Usability; Sistem Navigasi (Struktur); Desain Visual (Graphic Design); Konten (Contents); Kompabilitas (Compability); Lamanya Proses (Loading Time); Fungsionalitas (Fungsionality); Aksesibilitas (Accesibility); dan Interaktivitas (Interactivity).

Dalam perkembangan website yang sekarang banyak digunakan, banyak sekali desain tampilan yang belum memenuhi prinsipprinsip mendesain website yang baik dan benar. Sehingga muncul kesalahan-kesalahan yang sering terjadi dalam mendesain website dikelompokkan menjadi lima (5) kategori, yakni : Kesan pertama/gambar besar; Teks dan link; Grafik, video, dan audio; Navigasi; dan Konten.

Paper ini disusun agar bertujuan untuk mengetahui hasil analisis desain beberapa tampilan website berdasarkan buku "The Principle Beautiful Web Design" menggunakan tujuh variabel antara lain Defining good Design, Web Page Anatomy, Grid Theory, Balance, Unity, Bread and Butter Layout, dan Fresh Trends.

Untuk membuat desain website yang baik terdapat prinsip-prinsip yang dapat digunakan untuk membantu dalam proses mendesain. Ada banyak teori yang menjelaskan prinsip-prinsip tersebut. Diantaranya yaitu teori "the principle beautiful web design" yang didalamnya terdapat tigabelas variabel yang dapat digunakan sebagai prinsip dalam mendesain tampilan website yang baik. Dalam paper ini akan menggunakan tujuh variabel dari tigabelas variabel tersebut antara lain yaitu (Beaird, 2010):

Defining Good Desain, dalam mendefinisikan desain yang baik terdapat dua sudut pandang utama yang membuat kebanyakan orang menentukan tentang tampilan website, yaitu apakah desain situs web adalah 
"baik" atau "buruk." Ada juga sudut pandang yang kegunaan, yang berfokus pada fungsi, penyajian informasi yang efektif, dan efisiensi. Sehingga muncullah subvariabel untuk menentukan tampilan desain website yang benar yaitu Users are pleased by the design but drawn to the content, Users can move about easily via intuitive navigator, dan Users recognize each page as belonging to the site.

Web page Anatomy, bahkan dari sudut pandang non-desainer, mendefinisikan desain yang memenuhi semua persyaratan dalam anatomi halaman web ini adalah tugas sederhana. Anatomi dibagi dalam containing block, logo, navigation, content, footer, dan whitespace.

Grid Theory, Ketika kebanyakan orang berpikir tentang grid, mereka hanya berpikir tentang rekayasa dan arsitektur. Namun, grid adalah alat yang juga penting untuk desain grafis. Menggunakan grid bukan hanya tentang membuat hal-hal menjadi persegi dan berbaris: ini tentang proporsi juga. Di situlah "teori" datang ke dalam teori jaringan. Sehingga didalam variable teori grid terdapat subvariabel yaitu the rule of thirds.

Balance, Dalam arti kiasan, konsep keseimbangan visual mirip dengan keseimbangan fisik digambarkan oleh jungkatjungkit. Sama seperti benda-benda fisik memiliki berat badan, demikian juga unsur layout. Jika unsur-unsur di kedua sisi layout yang berat yang sama, mereka menyeimbangkan satu sama lain. Sehingga ada dua subvariabel dari balance: simetris dan asimetris.

Unity, teori desain menggambarkan kesatuan sebagai acuan pada cara di mana unsurunsur yang berbeda dari komposisi berinteraksi satu sama lain. Sebuah tata letak terpadu adalah salah satu yang bekerja sebagai keseluruhan daripada yang diidentifikasi sebagai bagian yang terpisah. Sangat penting bahwa unity tidak hanya ada dalam setiap elemen dari halaman web, tetapi di seluruh halaman-web page itu sendiri harus bekerja sebagai satu unit. Kita dapat menggunakan beberapa pendekatan untuk mencapai unity dalam sebuah layout (selain dari menghindari frame): yaitu subvariabel proximity dan repetition.

Bread and butter layouts, Ketika Anda sedang menggunakan internet, dan tampilan website muncul, Anda dapat melihat bahwa kemungkinan tata letak yang benar-benar tidak terbatas. Tapi, hanya beberapa kemungkinan yang masuk akal dalam desain website yang baik. Yaitu pada saat melihat konfigurasi tertentu dari identitas, navigasi, dan konten. Pada bread and butter ini, kita akan berbicara tentang layout yang digunakan dalam tampilan desain website. Subvariabelnya antara lain: left column navigation, right column navigation, dan three column navigation.

Fresh Trends, dengan melihat masa lalu warna dan tekstur pada kotak yang membentuk tata letak, lalu dilakukan percobaan untuk mengidentifikasi ide-ide umum dan tren desain. Sehingga dapat dihasilkan beberapa tren yang tampaknya akan muncul di layout situs website. Subvariabel antaralain: expansive footer navigation,dan three column with content first.

Pada penelitian (Djamasbi, Siegel, \& Tullis, 2010) menyebutkan bahwa Generasi Y (usia 18-31) adalah generasi yang sangat besar dan ekonomis kuat, mengandung 82.000.000 orang dan menghabiskan $\$ 200$ miliar per tahun. Hal ini tidak mengherankan bahwa perusahaan tertarik untuk mendapatkan perlindungan dari kelompok ini, terutama melalui web. Anehnya, sangat sedikit penelitian untuk membuat halaman web menarik bagi demografis penting ini telah dilakukan. Makalah ini membahas kebutuhan ini melalui dua studi terpisah. Pertama, survei online, memberikan bukti bahwa skor yang diusulkan untuk memprediksi daya tarik visual dari halaman web mencerminkan ukuran laporan diri dari apa yang suka halaman Generasi Y. Untuk memperbaiki temuan ini, sebuah studi pelacakan mata dilakukan menggunakan halaman yang paling dan paling disukai di gerakan mata Studi I. Peserta 'dilacak saat browsing halaman-halaman ini, memberikan bukti apa yang menarik perhatian mereka. Hasil dua studi ini menunjukkan bahwa Generasi $\mathrm{Y}$ dapat memilih halaman yang 
mencakup gambar utama besar, gambar selebriti, sedikit teks, dan fitur pencarian. Penelitian ini memiliki implikasi penting.

Sedangkan penelitian (Thorlacius, 2010) menyebutkan bahwa situs web yang cepat menjadi pilihan media yang lebih disukai untuk pencarian informasi, presentasi perusahaan, belanja, hiburan, pendidikan, dan kontak sosial. Dan bersama dengan berbagai bentuk komunikasi yang menawarkan Web aspek estetika telah mulai memainkan peran yang semakin penting. Namun, penelitian dalam desain dan relevansi berfokus pada aspek estetika dalam perencanaan dan menggunakan situs Web hanya untuk tingkat yang lebih kecil menjadi subyek dari refleksi teoretis. Misalnya, Miller (2000), Thorlacius (2001, 2002, 2005), Engholm (2002, 2003), dan Beaird (2007) telah memberikan kontribusi untuk menetapkan agenda awal yang membahas aspek estetika. Di sisi lain, ada cukup banyak literatur menangani aspek teoritis dan metodologis berfokus pada aspek teknis dan fungsional. Dalam konteks ini adalah tujuan dari artikel ini untuk memperkenalkan model untuk analisis komunikasi visual di website.

\section{METODE}

Teknik pengambilan sampel menggunakan purposive random sampling. Subyek penelitian ini adalah beberapa tampilan website yang sering diakses dan merupakan website dari beberapa bidang yang berbeda. Terdapat empat website yang akan dianalisis yang terdiri dari dua jenis website dalam bidang perbankan dan dua jenis website dalam bidang food company yaitu website BNI, website bank BUKOPIN, website Jco Donuts dan website McDonals.

Tabel 1. Variabel dan Subvariabel Penelitian

\begin{tabular}{|c|c|}
\hline Variable & Subvariable \\
\hline Design Process & $\begin{array}{l}\text { a. Discovery } \\
\text { b. Implementation }\end{array}$ \\
\hline Defining Good Design & $\begin{array}{l}\text { a. User are pleased by the design but drawn to the content } \\
b . \text { Users can move about easily via intuitive navigator } \\
\text { c. User recognize each page as belonging to the site }\end{array}$ \\
\hline Web Page Anatomy & $\begin{array}{ll}\text { a. } & \text { Containing Block } \\
b . & \text { Logo } \\
c . & \text { Navigation } \\
\text { d. } & \text { Content } \\
\text { e. } & \text { Footer } \\
f . & \text { Whitespace }\end{array}$ \\
\hline Grid Theory & a. The rule of thirds \\
\hline Balance & $\begin{array}{l}\text { a. Symmetrical balance } \\
\text { b. Asymmetrical balance }\end{array}$ \\
\hline Unity & $\begin{array}{ll}\text { a. } & \text { Proximity } \\
\text { b. } & \text { Repetition }\end{array}$ \\
\hline Emphasis & $\begin{array}{ll}\text { a. } & \text { Placement } \\
b . & \text { Continuance } \\
c . & \text { Isolation } \\
\text { d. } & \text { Contrast } \\
\text { e. } & \text { Proportion }\end{array}$ \\
\hline Bread and Butter Layouts & $\begin{array}{l}\text { a. Left column navigation } \\
b . \text { Right column navigation } \\
\text { c. Three column navigation }\end{array}$ \\
\hline Getting Inspired & a. Using a morgue file \\
\hline Fresh Trends & $\begin{array}{l}\text { a. Expansive footer navigation } \\
b . \text { Three column with content first }\end{array}$ \\
\hline Resizing : Fixed Width vs Liquid Width & a. An alternative : variable fixed widht layout \\
\hline Screen Resolution & - \\
\hline Application : Florida Country Tile & - \\
\hline
\end{tabular}


Pendekatan yang digunakan adalah pendekatan kualitatif. Metode yang digunakan adalah studi kasus. Variabel yang digunakan ada tujuh dari tigabelas variabel, sesuai dengan buku "The Principles of Beautiful Web Design". Tujuh variabel yang akan dianalisis yaitu Defining good Design, Web Page Anatomy, Grid
Theory, Balance, Unity, Bread and Butter Layout dan Fresh Trends.

\section{HASIL DAN PEMBAHASAN}

Hasil analisis desain website menggunakan buku "The Principles of Beautiful Web Design" telah dijabarkan seperti di bawah ini:

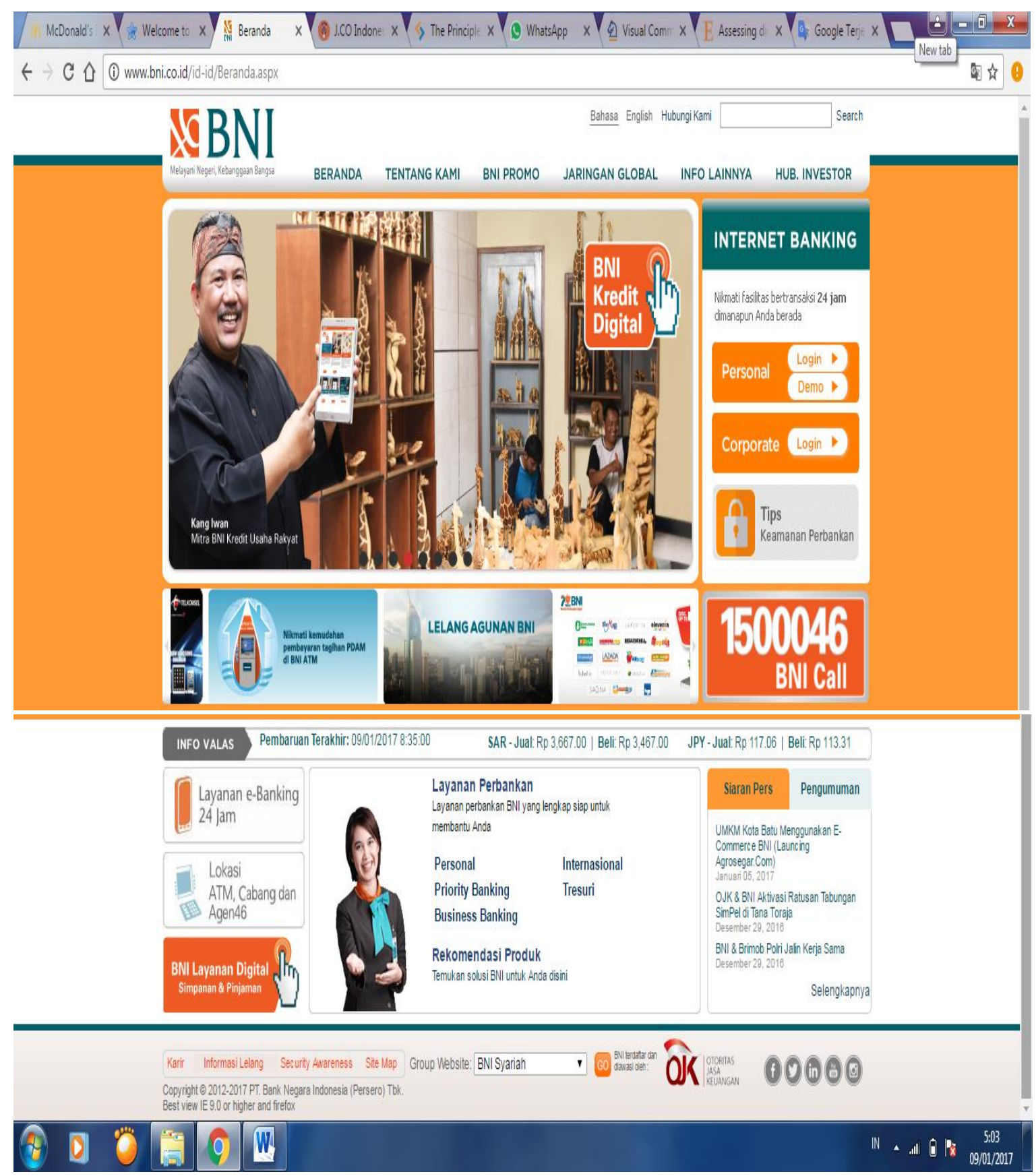

Gambar 1. Website bank BNI 
Bank Negara Indonesia atau BNI adalah sebuah institusi bank milik pemerintah, dalam hal ini adalah perusahaan BUMN, di Indonesia

\section{Defining good Design}

Pada variabel ini, Website BNI sudah menunjukan bahwa desain tampilan yang digunakan sudah baik. Dapat dilihat pada subvariabel User are pleased by the design but drawn to the content, website BNI telah menggunakan tamplate yang bisa membimbing pembaca untuk fokus pada konten, dikarenakan website menggunakan tamplate warna orange yang menjadi warna khas dari BNI sendiri.

Subvariabel Users can move about easily via intuitive navigator, navigasi disini sudah menggunakan standart dari penulisan tombol navigasi yang berupa huruf Kapital, sehingga pembaca mudah menjumpai navigasi tersebut.

Dan yang terakhir adalah subvariabel User recognize each page as belonging to the site, website BNI sangatlah mudah dikenali sebagai website dari BNI karena dominasi warna orange yang digunakan merupakan warna khas dari BNI.

\section{Web Page Anatomy}

Pada Variabel ini, desain website yang digunakan sudah memenuhi web page anatomi yang baik. Dapat dilihat pada subvariabelvariabelnya, website BNI ini memiliki Containing Block yang berpusat ditangah dan membentuk persegi panjang, Logo sudah sangat jelas terdapat di bagian kiri atas pada header, Navigation pada website BNI ini membentuk three column navigasi tetapi navigasi inti berada diatas pada header, Content terdapat di tengah tampilan website sehingga pembaca langsung bisa membaca konten dari website, Footer yang digunakan berwarna grey yang sangat baik digunakan untuk menandakan footer website, dan yang terakhir Whitespase yang digunakan sangatlah sedikit, itu sangat baik untuk memanfaatkan tampilan website sebagai konten.

\section{Grid Theory}

Pada website BNI ini variabel Grid Theory sudah digunakan dengan baik. Dilihat dari website yang menggunakan / mengikuti aturan pertiga vertikal dengan menggunakan garis yang menciptakan tiga kolom utama sebagai panduan alignment untuk blok identitas, navigasi, konten, dan footer dari atas ke bawah.

\section{Balance}

Pada variabel Balance yang terdapat pada website BNI ini menggunakan Symmetrical Balance. unsur-unsur di kedua sisi layout yang berat yang sama, mereka menyeimbangkan satu sama lain.

Sehingga website ini terlihat rapi dikarenakan balance secara horizontal terhadap sumbu tengah yang tegak lurus.

\section{Unity}

Dalam variabel ini, website BNI menggunakan pendekatan Repetition untuk menyatukan seluruh isi website. Pengulangan yang digunakan disini yaitu batas warna untuk setiap bagian dari website. Seperti antara header, konten, footer terdapat batas garis warna yang digunakan yaitu warna biru dan orange yang merupakan warna khas dari BNI.

\section{Bread and Butter Layout}

Dalam variabel Bread and Butter layout pada website BNI ini layout yang digunakan sudah baik. Pada website ini menggunakan three-column navigation, yang artinya Layout tiga kolom khas memiliki kolom tengah yang luas diapit oleh dua kolom navigasi kecil.

\section{Fresh Trends}

Pada website BNI ini menggunakan variabel Fresh Trends pada desain tampilan websitenya. Yaitu menggunakan Expansive Footer Navigation, menyertakan informasi kontak, navigasi situs diperluas, dan konten tambahan seperti twitter, Facebook, Youtube dan instagram. 


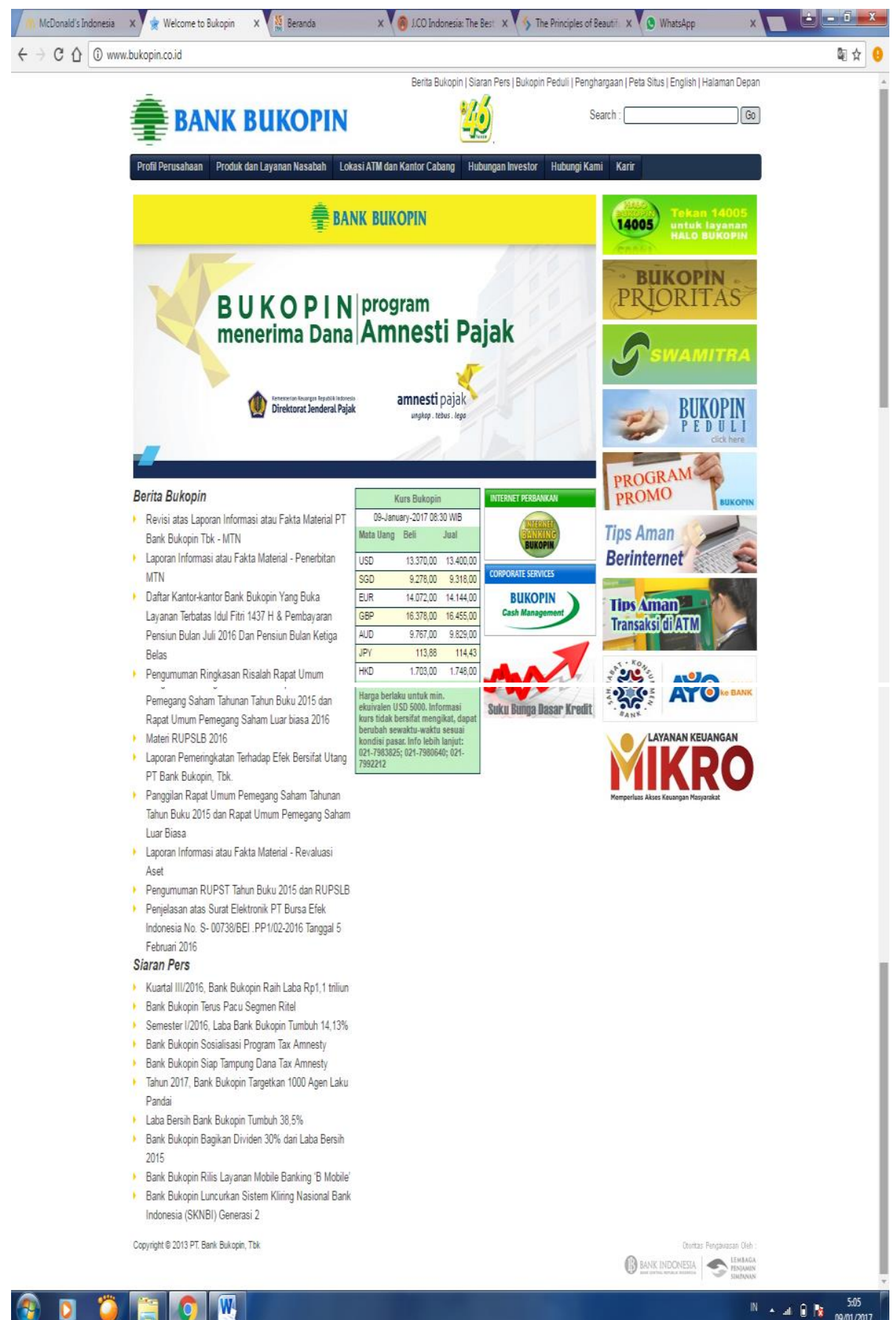

Gambar 2. Website bank BUKOPIN

Bank Bukopin adalah bank swasta kelas menengah di Indonesia dan memfokuskan bisnis intinya pada 4 sektor, yaitu UKM, mikro, konsumer, dan komersial.

\section{Defining good Design,}

Pada variabel ini, Website Bank Bukopin sudah menunjukan bahwa desain tampilan yang digunakan tidak terlalu buruk. Dapat dilihat pada subvariabel User are pleased by the design but drawn to the content, website Bank Bukopin telah menggunakan tamplate yang bisa membimbing pembaca untuk fokus pada konten, dikarenakan website menggunakan tamplate standart dari desain website, dan background yang digunakan hanya warna putih, sehingga pembaca langsung dapat membaca isi dari konten. 
Subvariabel Users can move about easily via intuitive navigator, navigasi juga menggunakan standart dari penulisan tombol navigasi yang berupa huruf Kapital dan diberi background warna hitam, sangat kontras dengan background website yang berwarna putih dan aksen warna hijau kuning yang menjadi warna khas dari Bank Bukopin, sehingga pembaca mudah menjumpai navigasi tersebut.

Terakhir adalah subvariabel User recognize each page as belonging to the site, website Bank Bukopin kurang dapat dikenali, dikarenakan kekhasan dr Bank Bukopin hanya terdapat di bagian header saja, sehingga jika discroll kebawah pembaca kurang bisa mengenali jika website itu Website Bank Bukopin.

\section{Web Page Anatomy}

Pada Variabel ini, desain website yang digunakan sudah sedikit memenuhi web page anatomi yang baik. Dapat dilihat pada subvariabel-variabelnya, website Bank Bukopin ini memiliki Containing Block yang berpusat ditangah dan membentuk persegi panjang, Logo sudah sangat jelas terdapat dibagian kiri atas pada header. Navigation pada website Bank Bukopin berada diatas pada header, Content terdapat pada bawah tampilan website sehingga pembaca langsung bisa membaca konten dari website, Footer yang digunakan tidak diberi pembatas warna sehingga menggu-nakan warna dasar yaitu putih, dan yang terakhir Whitespase yang digunakan sangatlah banyak, itu kurang baik dilakukan dalam mendesain website karena kurang memanfaatkan halaman untuk memuat konten dan dibiarkan kosong.

\section{Grid Theory}

Pada website Bank Bukopin ini variabel Grid Theory sudah digunakan dengan baik. Dilihat dari website yang menggunakan/mengikuti aturan pertiga vertikal dengan menggunakan garis yang menciptakan tiga kolom utama sebagai panduan alignment untuk blok identitas, navigasi, konten, dan footer dari atas ke bawah.
Pada variabel Balance yang terdapat pada website Bank Bukopin ini menggunkaan Asymmetrical Balance. Sehingga tampilan menggunakan desain yang tidak memiliki keseimbangan kanan kiri maupun atas bawah. Tetapi dengan asymmetrical balance website ini semakin jelas, karena pada website Bank Bukopin ini konten lebih besar sehingga lebih mudah ditemukan oleh pembaca.

\section{Unity}

Dalam variabel ini, website Bank Bukopin ini menggunakan pendekatan Proximity untuk menyatukan seluruh isi website. Kedekatan yang digunakan disini yaitu judul bagian yang dicetak dengan huruf Kapital dan diberi Bold. Sehingga pembaca mengetahui batas untuk setiap bagian dari website. Seperti antara header, konten, dan footer.

\section{Bread and Butter Layout}

Dalam variabel Bread and Butter layout pada website Bank Bukopin ini layout yang digunakan sudah baik. Pada website ini menggunakan three-column navigation, yang artinya Layout tiga kolom khas memiliki kolom tengah yang luas diapit oleh dua kolom navigasi kecil.

\section{Balance}




\section{Fresh Trends}

Pada website Bank Bukopin ini tidak menggunakan variabel Fresh Trends pada desain tampilan websitenya. Sehingga tampilan websitenya masih menggunakan tampilan website standar.

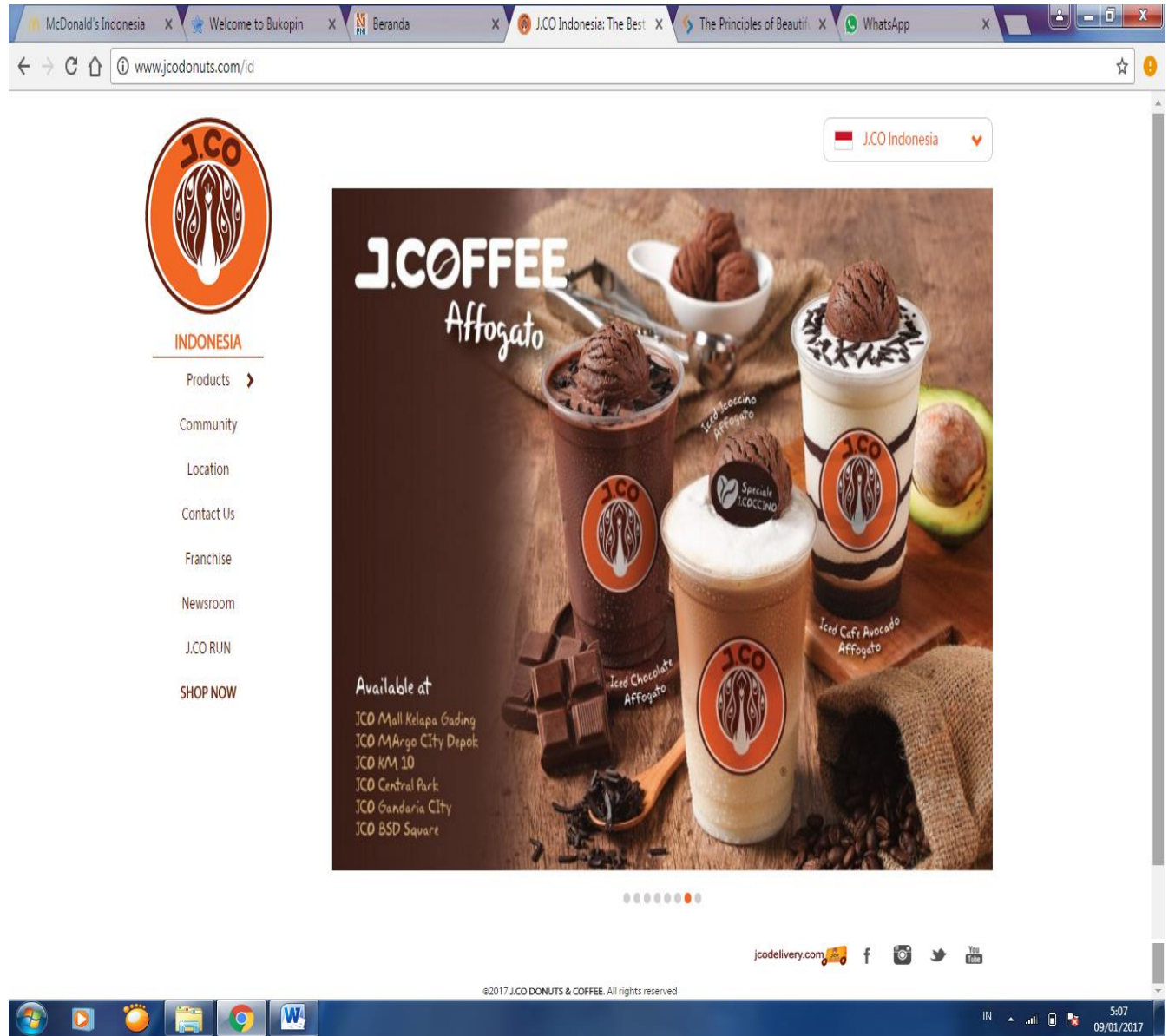

Gambar 3. Website Jco Donuts

J.CO Donuts adalah restoran dan waralaba yang mengkhususkan dalam donat, yogurt beku dan kopi. Perusahaan didirikan dan dimiliki oleh Johnny Andrean Group. J.CO Donuts \& Coffee didirikan tahun 2006.

\section{Defining good Design,}

Pada variabel ini, Website J.co Donuts sudah menunjukan bahwa desain tampilan yang digunakan tidak terlalu buruk. Dapat dilihat pada subvariabel User are pleased by the design but drawn to the content, website Jco Donuts telah menggunakan template yang bisa membimbing pembaca untuk fokus pada konten, dikarenakan website menggunakan template warna putih untuk menjadi background. Sehingga sangat kontras dengan konten yang berwarna coklat.
Subvariabel Users can move about easily via intuitive navigator, navigasi disini sudah sangat mudah dijumpai, dikarenakan letak navigasi yang terletak pada bagian kiri website dan berada jauh dari konten.

Dan yang terakhir adalah subvariabel User recognize each page as belonging to the site, website Jco Donuts mudah dikenali sebagai website dari Jco Donuts karena terdapat dominasi warna coklat dibagian konten. 


\section{Web Page Anatomy}

Pada Variabel ini, desain website yang digunakan sudah sedikit memenuhi web page anatomi yang baik. Dapat dilihat pada subvariabel-variabelnya, website Bank Jco Donuts ini memiliki Containing Block yang berpusat di tengah dan membentuk persegi saja, Logo sudah sangat jelas terdapat dibagian kiri atas pada header, Navigation pada website Jco Donuts berada dikiri website di bawah logo, Content berupa gambar terdapat pada sebelah kanan website, karena website hanya terdiri dari navigasi di sisi kiri dan content di sisi kanan, Footer yang digunakan tidak diberi pembatas warna sehingga menggunakan warna dasar yaitu putih, dan yang terakhir Whitespase yang digunakan sangatlah banyak, itu kurang baik dilakukan dalam mendesain website karena kurang memanfaatkan halaman untuk memuat konten dan dibiarkan kosong.

\section{Grid Theory}

Pada website Jco Donuts ini variabel Grid Theory sudah digunakan dengan baik. Dilihat dari website yang menggunakan/ mengikuti aturan perdua horizontal dengan menggunakan garis yang menciptakan dua kolom utama sebagai panduan alignment untuk blok identitas, navigasi, konten, dan footer dari kiri ke kanan

\section{Balance}

Pada variabel Balance yang terdapat pada website Jco Donuts ini menggunkaan Asymmetrical Balance. Sehingga tampilan menggunakan desain yang tidak memiliki keseimbangan kanan kiri maupun atas bawah. Tetapi dengan asymmetrical balance maka website ini semakin jelas, karena pada website Jco Donuts ini konten lebih besar sehingga lebih mudah ditemukan oleh pembaca.

\section{Unity}

Dalam variabel ini, website Jco Donuts ini menggunakan pendekatan Proximity untuk menyatukan seluruh isi website. Dikarenakan tampilan website yang hanya terdiri dari logo, navigasi, konten dan footer saja, maka Kedekatan yang digunakan sudah sangatlah jelas untuk pembaca mengetahui batas setiap bagian dari website. Seperti antara header, konten, footer.

\section{Bread and Butter Layout}

Dalam variabel Bread and Butter layout pada website Jco Donuts ini layout yang digunakan sudah baik. Pada website ini menggunakan left-column navigation, yang artinya navigasi hanya terletak pada bagian atas saja yaitu bagian header.

\section{Fresh Trends}

Pada website Jco Donuts ini menggunakan variabel Fresh Trends pada desain tampilan websitenya. Yaitu menggunakan Expansive Footer Navigation, menyertakan informasi kontak, navigasi situs diperluas yaitu jcodelivery.com, dan konten tambahan seperti twitter, Facebook, Youtube dan instagram. 


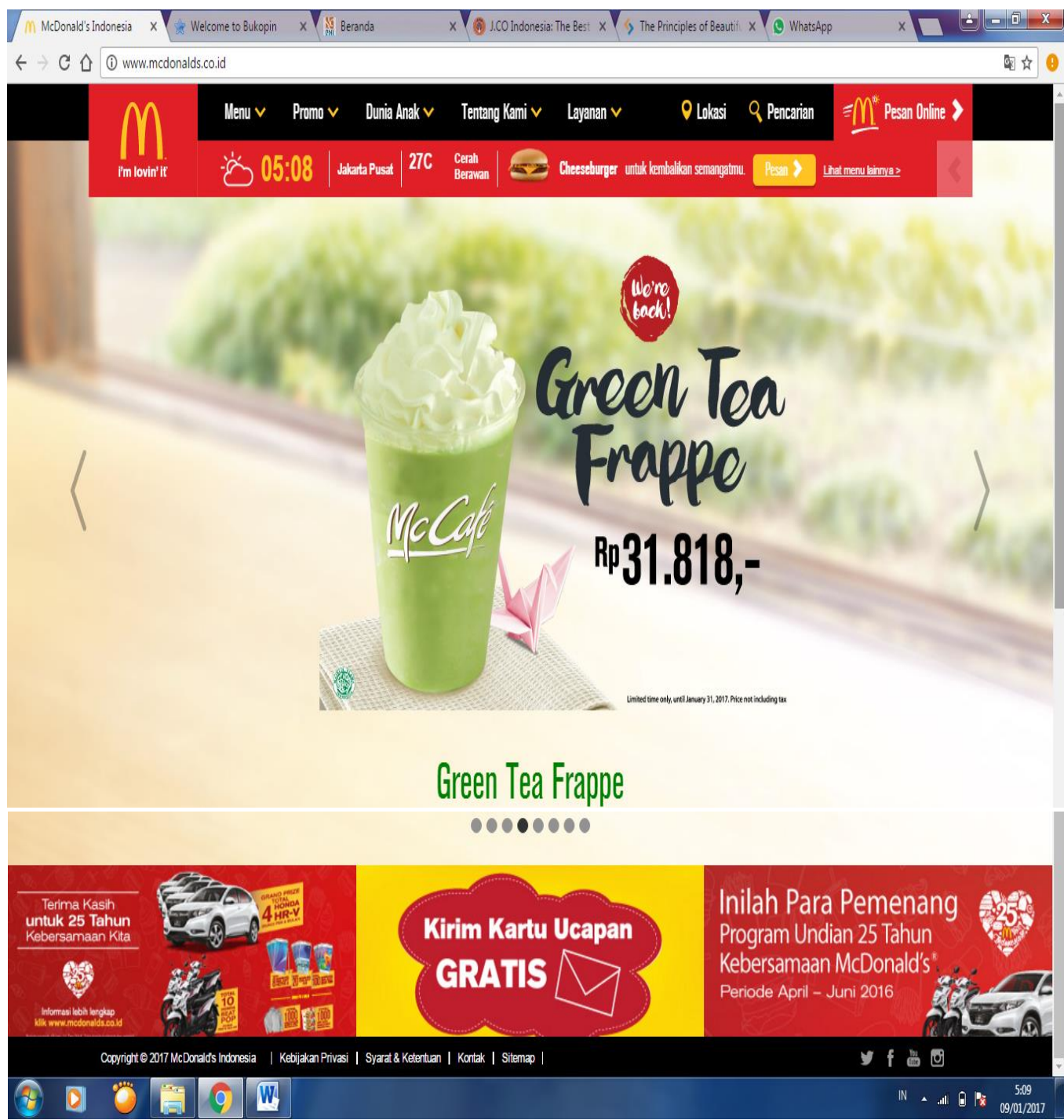

Gambar 4. Website McDonals

McDonald's adalah waralaba rumah makan siap saji terbesar di dunia. Hidangan utama di restoran-restoran McDonald's adalah hamburger, namun mereka juga menyajikan minuman ringan, kentang goreng dan hidangan-hidangan lokal yang disesuaikan dengan tempat restoran itu berada. Lambang McDonald's adalah dua busur berwarna kuning yang biasanya dipajang di luar rumah-rumah makan mereka dan dapat segera dikenali oleh masyarakat luas.

\section{Defining good Design}

Pada variabel ini, Website McDonals sudah menunjukan bahwa desain tampilan yang digunakan sudah baik. Dapat dilihat pada subvariabel User are pleased by the design but drawn to the content, website McDonals telah menggunakan tamplate gambar yang bisa membimbing pembaca untuk fokus pada konten yang berupa tulisan.

Subvariabel Users can move about easily via intuitive navigator, navigasi juga menggunakan standart dari penulisan tombol navigasi yang berupa huruf Kapital dan diberi background warna hitam, sangat kontras dengan background website yang berwarna putih dan navigasi terletak pada bagian atas website sehingga pembaca mudah menjumpai navigasi tersebut.

Terakhir adalah subvariabel User recognize each page as belonging to the site, website McDonals sangatlah mudah dikenali sebagai website dari McDonals karena dominasi warna merah yang digunakan merupakan warna khas dari McDonals. 


\section{Web Page Anatomy}

Pada Variabel ini, desain website yang digunakan sudah memenuhi web page anatomi yang baik. Dapat dilihat pada subvariabelvariabelnya, website McDonal ini memiliki Containing Block yang berpusat di tengah dan membentuk persegi panjang, Logo sudah sangat jelas terdapat dibagian kiri atas pada header, Navigation pada website McDonals berada diatas pada header, Content terdapat di tengah tampilan website sehingga pembaca langsung bisa membaca konten dari website, Footer yang digunakan berwarna hitam yang sangat baik digunakan untuk menandakan footer website, dan yang terakhir Whitespase yang digunakan sangatlah sedikit, itu sangat baik untuk memanfaatkan tampilan website sebagai konten.

\section{Grid Theory}

Pada website McDonal ini variabel Grid Theory sudah digunakan dengan baik. Dilihat dari website yang menggunakan/ mengikuti aturan pertiga vertikal dengan menggunakan garis yang menciptakan tiga kolom utama sebagai panduan alignment untuk blok identitas, navigasi, konten, dan footer dari atas ke bawah.

\section{Balance}

Pada variabel Balance yang terdapat pada website McDonals ini menggunakan Symmetrical Balance. unsur-unsur di kedua sisi layout yang berat yang sama, mereka menyeimbangkan satu sama lain. Sehingga website McDonals ini terlihat rapi dikarenakan balance secara horizontal terhadap sumbu tengah yang tegak lurus.

\section{Unity}

Tabel 2. Perbandingan Variabel pada Website BNI dengan Bank Bukopin
Website BNI
Dalam variabel ini, website McDonals menggunakan pendekatan Repetition untuk menyatukan seluruh isi website. Pengulangan yang digunakan disini yaitu batas warna untuk setiap bagian dari website. Seperti antara header, konten, footer terdapat batas garis warna yang digunakan yaitu warna merah dan orange yang merupakan warna khas dari McDonals.

\section{Bread and Butter Layout}

Dalam variabel Bread and Butter layout pada website McDonals ini layout yang digunakan sudah baik. Pada website ini menggunakan top-column navigation, yang artinya navigasi hanya terletak pada bagian atas saja yaitu bagian header.

\section{Fresh Trends}

Pada website McDonals ini menggunakan variabel Fresh Trends pada desain tampilan websitenya. Yaitu menggunakan Expansive Footer Navigation, menyertakan informasi kontak, navigasi situs diperluas, dan konten tambahan seperti twitter, Facebook, Youtube dan instagram.

\section{Website Perbankan (Website BNI vs Website Bank Bukopin)}

Dapat disimpulkan bahwa desain tampilan website BNI lebih baik dibandingkan website Bank Bukopin. Dikarenakan seluruh variabel yang ada digunakan semua pada Website BNI. Sedangakan pada website Bank Bukopin lemah di dalam variabel Defining Good Design, Web Page Anatomi dan Fresh Trends. Perbandingan variabel dapat dilihat pada Tabel 2.

\begin{tabular}{lll}
\hline \multicolumn{1}{c}{ Variabel } & \multicolumn{1}{c}{ Website BNI } & Website Bank Bukopin \\
\hline Defining Good Design & Baik & Kurang Baik \\
\hline Web Page Anatomy & Sudah Memenuhi & Sedikit Memenuhi \\
\hline Grid Theory & Digunakan dengan Baik & Digunakan dengan Baik \\
\hline Balance & Symmetrical Balance & Asymmetrical Balance \\
\hline Unity & Repetition & Proximity \\
\hline
\end{tabular}




\begin{tabular}{lll}
\hline Bread and Butter Layouts & three-column navigation & three-column navigation \\
\hline Fresh Trends & Ada, menggunakan Expansive Footer & Tidak Ada \\
& Navigation & \\
\hline
\end{tabular}

\section{Website Food Company (Website J.co Donuts vs Website McDonals)}

Dapat disimpulkan bahwa sebenarnya kedua website tersebut yaitu website J.co Donuts dan website McDonals sudah dapat dikatakan sebagai desain tampilan website yang baik. Akan tetapi website McDonals jauh sedikit lebih baik dibandingkan website J.co Donuts. Dikarenakan pada website McDonals menerapkan seluruh variabel. Sedangkan pada website J.co memiliki kelemahan di variabel Defining Good Design dan Variabel Web Page Anatomy. Perbandingan variabel dapat dilihat pada Tabel 3.

Tabel 3. Perbandingan Variabel pada Website J.co Donuts dengan McDonalds

\begin{tabular}{|c|c|c|}
\hline Variabel & Website J.co Donuts & Website McDonals \\
\hline Defining Good Design & Kurang Baik & Baik \\
\hline Web Page Anatomy & Sedikit Memenuhi & Sudah Memenuhi \\
\hline Grid Theory & Digunakan dengan Baik & Digunakan dengan Baik \\
\hline Balance & Asymmetrical Balance & Symmetrical Balance \\
\hline Unity & Proximity & Repetition \\
\hline Bread and Butter Layouts & left-column navigation & three-column navigation \\
\hline Fresh Trends & $\begin{array}{l}\text { Ada, menggunakan Expansive } \\
\text { Footer Navigation }\end{array}$ & $\begin{array}{l}\text { Ada, menggunakan Expansive } \\
\text { Footer Navigation }\end{array}$ \\
\hline
\end{tabular}

Website perbankan vs Website Food Company

Dapat disimpulkan bahwa Website Food Company sedikit lebih baik desain tampilan websitenya dibandingkan website perbankan.

Karena sesuai dengan tujuan website, website food company memiliki tujuan untuk menarik hati pelanggan untuk membeli atau menikmati menu yang ditawarkan. Sehingga dalam desain tampilan websitenya, hampir seluruh variabel menjadi acuan dalam mendesain tampilan websitenya.

\section{SIMPULAN}

Simpulan yang dapat diambil dari analisis desain website teori The Principle of Beautiful Web Design adalah sebagai berikut: 1) Website BNI kuat di seluruh variable; 2) Website Bank Bukopin lemah di variabel
Defining Good Design, Web Page Anatomi dan Fresh Trends; 3) Website J.co Donuts lemah di variabel Defining Good Design dan Variabel Web Page Anatomy; 4) Website McDonals kuat di seluruh variable; 5) Website Perbankan dalam desain tampilan, website BNI lebih baik dibandingkan website Bank Bukopin; 6) Website Food Company dalam desain tampilan, website McDonals lebih baik dibandingkan website J.co Donuts; 7) Website Food Company memiliki desain tampilan lebih baik dibanding Website Perbankan.

\section{DAFTAR RUJUKAN}

Beaird, J. (2010). The Principles of Beautiful Web Design. Canada: SitePoint.

Djamasbi, S., Siegel, M., \& Tullis, T. (2010). Generation Y, web design, and eye 
tracking. International Journal of Human-Computer Studies, 307-323.

Thorlacius, L. (2010). Visual Communication in Web Design - Analyzing Visual Communication in Web Design. In Institute of Communications, Business and Informat, International Handbook of Internet Research (pp. 455-476). Denmark: Springer Netherlands. 